\title{
ІНТЕРПРЕТАЦІЯ ВНУТРІШНЬОЇ ФОРМИ БІБЛІЙНИХ ФРАЗЕОЛОГІЗМІВ - АКТУАЛЬНА ПРОБЛЕМА ТЕОЛІНГВІСТИКИ
}

У пропонованій статті розглядається вплив лінгвістичних ідей О. Потебні на становлення української теолінгвістики, важливість учення про внутрішню форму слова для інтерпретації значення біблійних фразеологізмів, розкриття механізмів семантичних девіацій. Висновкуємо, що серед бібліїзмів є чималий пласт бібліїзмів-радянізмів. Незрозумілість висловів із затемненою внутрішньою формою була стимулом до стилістичного перемімення деяких бібліїзмів в несакральну сферу, а самі постбіблійні вислови стали вживатися зі значенням, омонімічним до первинного. Наявність прозорої внутрішньої форми спричиняє появу нових бібліїзмів у сучасних мовах.

Ключові слова: бібліїзм, бібліїзм-радянізм, внутрішня форма, семантична девіація, теолінгвістика, церковнослов'янізм.

Piddubna N. Interpretation of the Internal Form of Biblicalisms as an Urgent Problem of Theolinguistics. Theolinguistics as a scientific field that studies the interaction of language and religion has a multi-vector nature, aimed at the phenomenon of biblicality - the influence of the Bible on the Ukrainian language at all levels of the language system.

O. Potebnya's ideas, his thoughts on the connection of human consciousness with the language, mythical and non-mythical forms of consciousness and thinking played an important role in the formation of Ukrainian theolinguistics.

A significant part of the transliteration of biblical phraseology has variants that arose as a result of the tendency to repel from Church Slavonicism. That was predetermined with the obscure internal form which wass connected with the usage of opaque lexemes, Church Slavonicisms. The study of the internal form of the word is important for the interpretation of the meaning of biblical phraseology, the disclosure of the mechanisms of semantic deviations related to the process of functioning of biblicalisms. The obscure internal form causes the appearance of "conservative"-biblicalisms, which as actualized units are often subject to dysfunctional use, culturological and linguistic distortions. Phraseological biblicalisms with archaic components and, accordingly, an obscure internal form, can undergo noticeable formal and semantic deformations, which even lead to the formation of special phraseological units, which are common only in some languages. Obscure internal form allows the appearance of a special group - biblical-Sovietisms.

We conclude that there is a considerable layer of biblical-Sovietisms among biblicalisms. The incomprehensibility of the expressions with the obscure internal form 
was a stimulus to stylistic shift of some biblicalisms into non-sacramental sphere. The post-biblicalisms were used with the homonymous meaning to their original one. The presence of an obscure internal form leads to the appearance of new biblicalisms in modern languages.

Keywords: biblicalism, biblical-Sovietisms, internal form, semantic deviation, theolinguistics, Church Slavonicism.

\section{Вступ}

Мовознавство потрапило сьогодні в центр системи гуманітарних наук. Характерна ознака сучасної лінгвістики - міждисциплінарність. На межі різних наукових галузей розбудовуються нові наукові напрями, серед яких чимало й суперечливих. До них належать, наприклад, такі, як медична лінгвістика, юридична лінгвістика, лінгвістика емоцій, лінгвістика брехні та под. Зазначене стосується, зокрема, і теолінгвістики, що виникла на межі релігієзнавства й лінгвістики.

Сучасні мовознавці неоднозначно сприймають і термін теолінгвістика, i, відповідно, науку, що цим терміном позначається. Ïї трактують як науковий напрям, що окреслює проблематику, яка торкається питань взаємодії мови й релігії. Зрозуміло, що об'єкт теолінгвістики як синтетичної науки визначити складно, оскільки «здійснюється об'єднання в єдиному мисленнєвому просторі концептуальних уявлень з різних дисциплін або навіть сфер знань» (Постовалова, 2012: 59). Об'єктом теолінгвістики пропонують уважати релігійну (сакральну, літургійну, молитовну) мову (мовлення), релігійний дискурс і релігійну комунікацію, де поняття релігійної картини світу розглядається як наслідок релігійного світоспоглядання homo religiosus'a (Буевич, 2013: 133), що цілком слушно. Але об’єкт теолінгвістики - це не лише релігійна мова, а також «етапи розвитку мовознавства, історія мовознавства, що зумовлені конфесійними причинами; теорії походження мови (передусім теорія божественної сутності походження мови) й інші питання - одним словом, усі явища, пов'язані з Богом, що закріпилися й відбилися в мові» (Бугаева, 2015: 295), однак, як видається, у цьому разі вже йдеться про дослідницький предмет. Авторка цієї розвідки трактує об'єкт теолінгвістики як такий, що має багатовекторний характер: це комплекс аспектів взаємодії релігії і мови, фіксація релігійної свідомості в МКС, iï поступ, зміни, особливості функціювання одиниць мовної системи в релігійному дискурсі, релігійній комунікації, мовному просторі 
конкретної лінгвокультури загалом, тобто широкі можливості відображення кожної релігії в кожній конкретній мові.

У сучасній славістиці одним з підходів до розуміння теолінгвістики (О. Гадомський, Г. Гадомська, Ю. Чернишова, А. Буєвич) $€$ скерування на з'ясування механізмів взаємозв'язку мови й релігії, відбиття релігійних чинників у мові, розробка «універсальної схеми взаємозв’язку природної людської мови й релігії незалежно від іiї конкретно-конфесійних проявів» (Постовалова, 2012: 68). 3 огляду наведеного вище важливим уважаємо дослідження феномену біблійності - впливу Біблії на українську мову, що виявляється й у внутрішній формі (ВФ) фразеологічних бібліїмів. Зазначене й зумовлює актуальність цієї розвідки.

Проблеми релігійної мови, зв'язку мови й релігії актуалізувалися виключно в сучасному мовознавстві, але їх торкалися й класики мовознавчої науки. Суттєвий вплив на формування української теолінгвістики мали передусім ідеї О. Потебні, виражені в низці його робіт: «Мысль и язык» (Потебня, 1989), «Обзор поэтических мотивов колядок и щедровок» (Потебня, 1887), «О некоторых символах в славянской народной поэзии» (Потебня, 1860), «Символ и миф в народной культуре» (Потебня, 2000).

О. Потебня не підтримував «божественної» теорії походження мови, однак інші його ідеї мали плідне продовження в проєкції на проблематику теолінгвістики. Зокрема, думка вченого про вплив мови на міфологічну й релігійну свідомість виразно окреслюється тоді, коли йдеться про перетин мовних і міфологічних систем, як це сталося, наприклад, у процесі «накладання» християнства на язичництво. У подальшому ці ідеї розвивали Е. Сепір та Б. Уорф, а в славістиці вони знайшли продовження в працях Б. Успенського і Ю. Лотмана (Лотман, \& Успенский, 1973: 282-305).

Теоретичні розробки О. Потебні про зв'язок свідомості людини з їі мовою, міфічні й неміфічні форми свідомості та мислення, учення про ВФ слова послугували основою для «виокремлення в конфесійних мовах сталих змістовних форм, що є незмінними в межах всіх богослужбових мов певної конфесії, і форм вираження, які під впливом граматичних форм національних мов по-своєму варіюють в різних сакральних мовах християнських конфесій», що запропонувала I. Богачевська (Богачевська, 1998: 10). В основу проведеного нею аналізу 
сакральної мови православ'я покладені ідеї О. Потебні про особливості релігійного мислення та його зв'язки з національною мовою (там само).

Важливими для теолінгвістики є й думки О. Потебні щодо категорії образності: «Усі значення в мові за походженням образні, кожне може з плином часу стати безобразним» (Потебня, 1905: 203), що відбувається у зв'язку із забуванням вихідного мотивування, затемненням ВФ.

Мета цієї статті - з'ясувати особливості впливу ВФ фразеологічних бібліїзмів на інтерпретацію їхніх значень. Зазначена мета передбачає розв'язання таких завдань: 1) продемонструвати вплив лінгвістичних ідей О. Потебні на становлення української теолінгвістики, важливість учення про ВФ слова для розуміння значення біблійних фразеологізмів; 2) описати вплив ВФ фразеологічних бібліїзмів на їхню семантичну специфіку; 3) висвітлити особливості функціювання досліджуваних одиниць у сучасній українській мові.

\section{Методи дослідження}

У процесі дослідження було застосовано такі методи: концептуально-аналітичний, що сприяв кваліфікації й методологічній оцінці теоретичних положень теолінгвістики; аксіологічний метод використано для з'ясування ціннісних орієнтацій авторів досліджуваних праць, для аналізу зібраного матеріалу актуалізовано описовий метод, аналізу та синтезу (для здійснення теоретичних узагальнень і систематизації фактичного матеріалу).

\section{Виклад основного матеріалу}

Попри деякі розбіжності, науковці відносять до складу бібліїзмів і фразеологізми, порівн.: «Бібліїзми - вислови зі Святого Письма, що вживаються в літературній мові, зокрема в художньому та публіцистичному стилях, з метою створення словесно-художніх образів. Напр.: нести свій хрест, адамові діти, святая святих, вавилонське стовпотворіння» (Єрмоленко, Бибик, \& Тодор, 2001: 23). Серед них i транслітерні фразеологізми-церковнослов'янізми, які можуть мати варіанти, що виникли внаслідок тенденції «відштовхування» від церковнослов'янізмів. Це зумовлене й затемненою ВФ, пов’язане 3 уживанням незрозумілих лексем-церковнослов'янізмів: алчущі іжаждущі - спраглі і голодні; віра горами двигає - віра горами рухає; 
глас вопіющого в пустині - голос волаючого в пустелі; гроби поваплені - гроби побілені; юдоль плачу - долина плачу; земля обітована - обітована земля - обіияна земля та ін. Наявність варіантних змін у системі біблійних фразеологізмів підтверджує тезу про те, що вони не є статичними, а репрезентують «живий і рухливий, постійно змінюваний мовний матеріал, що підтверджує його системний характер. Через варіативність відбувається розвиток фразеологічної підсистеми мови: первинно з'являючись у мовленні, варіанти біблійних фразеологічних одиниць фіксуються потім і в мовній системі» (Багдасарян, \& Федуленкова, 2014: 385). Отже, наявність у складі ФО церковнослов'янізмів різного типу, «законсервованих» біблійними крилатими висловами, є однією з головних, однак не обов'язкових (факультативних) експліцитних параметрів біблійної маркованості, оскільки (1) у багатьох ФО-бібліїзмах церковнослов'янізми замінені українськими словами; (2) наявність власних імен й архаїзмів біблійного походження у складі сполучень слів й афоризмів далеко не завжди свідчить про їхню належність до корпусу бібліїзмів (Chlebda, 2002: 86-87).

Питання вживання - невживання церковнослов'янізмів не лише в складі бібліїзмів, але й в українській богослужбовій мові загалом ще й досі залишається дискусійним, причому дехто з дослідників, як правило, прихильників Московського патріархату, убачає у відмові від них мало не загрозу православ’ю й культурі загалом. На жаль, особливо категорично такі міркування висловлюють деякі російські науковці, напр., Г. Трубіцина, переймаючись долею Православної церкви й, як не дивно, української мови, ототожнює церковнослов'янізми 3 так званими «москальськими» елементами, від яких нібито категорично відмовляється українська мова, порівн. у наведеному нижче мовою оригіналу поклику: «Жаль, что переводчики Н. В. Гоголя на спешно создаваемый украинский литературный язык не понимают, что, отвергая все «москальское», они отвергают мировую культуру, загоняя себя в узкие националистические рамки и подрывая православное мировоззрение множественными заимствованиями из польского, выросшего на католической почве» (Трубицина, 2011). Ця думка видається ще більш категоричною, ба навіть агресивною, на тлі міркувань іншого знаного російського лінгвіста В. Мокієнка, який як характерну рису російської лексики й фразеології відзначає симбіоз 
«Свого» й «Чужого», що «значно збагатив склад бібліїзмів і зробив 3 деяких із них структурно, семантично, стилістично, а тим самим і національно марковані» (Мокиенко, 2014: 420).

Дійсно, основним джерелом проникнення в українську мову бібліїзмів $є$ церковнослов'янська мова. Саме тому значна їх кількість в українській мові вживається 3 помітними вкрапленнями церковнослов'янізмів, напр., "Блажен муж, щзо не йде на раду нечестивих», а то й просто церковнослов'янською, порівн.: «Камо грядеши?» (Коваль, 2012: 9), які Ж. Колоїз і З. Бакум називають транслітерними фраземами біблійного походження (Колоїз, \& Бакум, 2001: 48-49). Можливо, саме тому деякі науковці (О. Ахманова, Є. Верещагін) ототожнюють бібліїзми із церковнослов'янізмами, що не беззаперечно, оскільки біблійні цитати, стаючи крилатими, традиційно «можуть уживатись як українською, так і іншими мовами: «Хай буде світло!» - ми кажемо ще й «Fiat lux!» - латинською; «Алілуя!» («Хвала Богу!») - староєврейською» (Коваль, 2012: 9). Утім, не всі бібліїзми потрапили в українську мову через церковнослов'янську, адже багато 3 них входило в східнослов'янські мови через літературні пам'ятки Київської Русі, писані давньоруською мовою, зокрема через повчальну літературу Давньої Русі, патристику. Потужним джерелом поповнення української мови бібліїзмами були барокові гомілійні тексти. О. Зелінська зауважує, що «проповідницькі твори сприяли засвоєнню біблійних порівнянь, які набули статусу стійких і закріпилися у фразеологічній системі української мови» (Зелінська, 2013: 271), напр., як зіницю ока берегти. Названа дослідниця припускає, що «через посередництво гомілійної літератури з джерел Святого Письма в українському лексиконі закріпився образ огнистого слова» (Зелінська, 2013: 321), який уживав у своїх проповідях І. Галятовський, а пізніше розвивали інші українські письменники.

Посередником поповнення бібліїзмами української мови, як і інших мов, також стали твори світової художньої й публіцистичної літератури, як напр., фразеологізм вежа зі слонової кістки. Ця ФО прийшла з французької мови й поширилася завдяки творчості Шарля Огюстена Сент-Бева (1804-1869). У наведеному крилатому вислові, що «вживається для характеристики індивідуальної творчості, відірваної від життя, чужої народові» (Коваль, \& Коптілов, 1975: 35), прочитуються біблійні алюзії, порівн.: I Я розіб’ю дім зимовий разом 
з домом тітнім, і загинуть доми із слонової кости, $i$ не стане багато домів, говорить Господь (Ам., 3: 15); Ви вилежуєтеся на ложах з слонової кости і вивалюєтесь на постелях своїх, і їсте баранів із отари та ситих телят із обори (Ам., 6: 4); блажен, хто вірить - цитата 3 комедії О. Грибоєдова «Горе от ума» (Коваль, \& Коптілов, 1975: 26), що набула поширення в українській мові через російську, хоч цей вислів є й у самій Біблії (Євангеліє від Івана, 20: 29).

В українській мові також наявні ФО-бібліїзми, які В. Мокієнко назвав бібліїзмами-«консервантами», тобто такими, у яких затемнена ВФ або архаїчна мовна структура (Мокиенко, 2014: 420), напр.: внести свою лепту; лепта вдовиці; на злобу дня; тємна вода во облацех; во главу угла; блажен, іже скоти милує; на отмщеніє язикам та ін. У них простежуємо особливу експресивність, генеровану опозицією, що виникає «між їхньою всім відомою синхронною семантикою й активною вживаністю й загадковістю, затемненістю їхнього діахронічного змісту й форми» (Мокиенко, 2014: 420). Виокремлений тип моделює таку типологійну опозицію: бібліїзми з прозорою ВФ бібліїзми-«консерванти» (бібліїзми із затемненою ВФ).

Однак через незнання глибинного змісту першоджерела - Біблії - бібліїзми як актуалізовані одиниці часто зазнають дисфункційного використання, тобто трапляються випадки, коли автор приписує лексемі неправильне значення й виникає ефект, не планований автором відповідного повідомлення або ж наслідком функціювання «незрозумілого в зрозумілому» (В. Мокієнко), зокрема церковнослов'янських слів у складі бібліїзмів. Натрапляємо й на помилкові вживання бібліїзмів, їхні культурологічні й мовні спотворення на зразок вносити вагому лепту, вносити велику лепту (Мокиенко, 2014: 426), які виникли як наслідок неправильного розуміння лексеми лепта, що, за СУМ-11, первинно мала значення: «1. У стародавньому Єрусалимі та в Греції - дрібна монета», а пізніше стала полісемантичною, розширивши значення такими ЛСВ, як «2. перен., книжн. Посильне подаяння, пожертвування або милостиня; 3. перен., уроч. Вклад у яку-небудь суспільну справу // Частка чого-небудь» (СУМ, т. 4: 478). Порівн.: лепта вдовиці - “порівняно невеликий, убогий вклад у що-небудь спільне” (СУМ, т. 4: 478).

Отже, можна стверджувати наявність бібліїзмів-семантичних девіацій, тобто таких, значення яких спотворене. Запобігає появі 
таких неправильних уживань, по-перше, гарне знання першоджерела, тобто Біблії, а також, як зауважує В. Мокієнко, у багатьох мовах - переклади цього біблійного висловлення з використанням семантично й культурологічно прозорого компонента (Мокиенко, 2014: 426), порівн. чеськ. Přispět svou hřivnou, польськ. Wnieść swój wklad, болг. внеса своя дял, нім. Scherflein dazu geben; фр. Apporter son obole та ін. Зауважмо, що в низці українських перекладів Біблії, замість екзотичної для українців назви дрібної монети лепта, ужито зрозумілі українцям найменування шеляг (І. Огієнко), шаг (І. Хоменко), гріш (П. Морачевський), мідяк (П. Куліш) (див. детальніше: Ботвин, 2020: 167-168), що, однак, не стали компонентами ФО.

До слова, В. Мокієнко уналежнює ФО лепта вдовиці до розряду біліїзів-радянізмів, показуючи, як незнання «вартісної» характеристики лепти призводить до парадоксального завищення їі грошового достоїнства й тим самим неправильного вживання фразеологізму (Мокиенко, 2014: 426).

ФО-бібліїзми з архаїчними компонентами й, відповідно, затемненою ВФ, можуть зазнавати помітних формальних і семантичних деформацій, що спричиняє навіть утворення особливих фразеологізмів, які виявляються лише в деяких мовах, як це, напр., сталося з популярним фразеологізмом злоба дня - 'те, що привертає увагу, цікавить усіх у даний момент' (СУМ, т. 3: 597), на злобу дня (nuсати, відгукуватися і т. ін.) - 'на важливі, актуальні теми' (СФУМ, 2008: 267), що з'явилися внаслідок неточного перекладу з давньогрецької мови полісемантичної лексеми kakia, ужитої в біблійному вислові $A r$ keton tei hemerai kakia autes. Ця лексема слугує для узагальнювальної характеристики всього негарного й залежно від контексту вона може позначати систему негативних понять, зокрема негіднісmь, nорочність, неприємність, неприязнь тощо.

У більш пізніх перекладах Євангелія і російською, й українською мовами слова злоба немає, порівн.: Кожний день має досить своєї mурботи! (Євангеліє від Матвія, 6: 34). Перекладачі з давньогрецької невдало трансформували його саме як злоба, а його вживання в складі вислову на злобу дня спочатку виражало жарт, а потім вислів усталився з переосмисленням лексеми злоба (Мокиенко, 2014: 424). Його використовують у мовах, де простежується тісний зв'язок із церковнослов'янським текстом Біблії - російській, українській, 
білоруській, болгарській. В інших мовах його не вживають, а значення - 'те, що привертає увагу, цікавить усіх у даний момент' - передається за допомогою інших сполучень слів, непов'язаних із сакральним текстом (Мокиенко, 2014: 425). У сучасних мовах він виявив свої дериваційні потенції, що демонструють похідні злободенний - 'той, що привертає увагу, цікавий для всіх у певний час, тепер', злободенність - 'абстр. до злободенний (СУМ, т. 3: 598), ставши радянізмом, оскільки багато газет так називали рубрики з інформацією про актуальні події (Мокиенко, 2014: 425).

Отже, серед бібліїзмів простежуємо пласт бібліїзмів-радянізмів. Незрозумілість висловів із затемненою ВФ була стимулом до стилістичного переміщення бібліїзму в несакральну сферу - радянізм, а сам постбіблійний вислів став уживатися зі значенням, омонімічним до первинного.

Як і мова загалом, система бібліїзмів не є закритою й статичною: вона, без сумніву, відкрита й динамічна. Попри загальну центральну тенденцію до зменшення бібліїзмів, зокрема фразеологізмів, їхній корпус поповнюється й нині, щоправда «нові прямі бібліїзми, за рідкісними винятками, не виникають, якщо в сучасній мові з'являється новий прямий бібліїзм; він, як правило, виникає не безпосередньо на основі Священного Письма, а калькуванням з іншої мови» (Фойту, 2013: 189). Напр., в українську мову через російську потрапив згаданий у Євангеліях кілька разів (Коваль, 2012: 165) прямий (контекстуальний) бібліїзм з прозорою ВФ Іди $і$ дивись!, що зумовлене виходом на екрани 1985 року художнього фільму з відповідною назвою «Іди і дивись» режисера Е. Климова, або поява бібліїзму білі шати, зумовлена виходом у 1988 році роману російського письменника В. Дудінцева «Белые одежды», перекладеного українською мовою В. Положієм (1989) як «Білі шати» (відповідний вислів $€$ в українських перекладах Біблії, порівн.....а на престолах я бачив двадиятьох чотирьох старцив, що сиділи, у шати білі одягнені...(Об'явлення 4:4)), хоч у Біблії функціює й вислів біла одежа, порівн.: Переможещь зодягнеться в білу одежу...(Об'явлення 3: 5)).

Через англійську мову, а саме з американського політичного дискурсу, а також унаслідок виходу у світовий прокат американського фільму «Армагедон» (1998, режисер М. Бей) в українську мову потрапив бібліїзм Армагедон, що синонімічний традиційному в українському мовному просторі Апокаліпсис. Фіксації цього нового бібліїзму 
в публіцистичних контекстах «показують динамічність і таких біблійних «неологізмів», засвідчуючи їхню життєвість і популярність» (Мокиенко, 2013: 149).

Найбільш активно, за авторськими спостереженнями, поповнюється група непрямих (ситуативних, експліцитних) біблійних фразеологізмів, напр., апокаліптичний переляк - 'почуття великого переляку, жах', порівн.: Він неохоче підводиться, визирає у вікно, бачить, хто там унизу стукає, і на його облчччі апокаліптичний переляк (Є. Кононенко). Часто вони мають жартівливу тональність, їхня експресивність вибудовується не на авторитеті Біблії, як це фіксуємо в цитатних бібліїзмах, а на «несумісності значення або стилістичного забарвлення з Біблією, суперечності з біблійними цінностями» (Фойту, 2013: 190), що спостерігаємо, напр., у висловах непорочне зачаття, завагітніти від ангела 'про вагітну незаміжню жінку', експресивність яких грунтується на несумісності сюжету Біблії і їхнього значення.

Динаміка прямих і непрямих біблійних фразеологізмів суттєво відрізняється, оскільки серед прямих бібліїзмів зміни скеровані на архаїзацію, забування мотивації і, як наслідок, зникненням з мови, тоді як серед ситуативних (непрямих) бібліїзмів більш виражений процес розвитку нових значень (полісемія, а іноді й енантиосемія), виникнення синонімічних зворотів, а також створення нових одиниць (див. докладно: Фойту, 2013: 190-192). Аналіз дослідницького матеріалу іï підтверджує.

\section{Висновки}

Отже, безперечно, творча спадщина О. Потебні має різноаспектний вплив на становлення теорії української теолінгвістики. Учення про ВФ слова й образність $є$ ключовими для розуміння значення біблійних фразеологізмів, розкриття механізмів виникнення семантичних девіацій, які виявляються під час функціювання бібліїзмів, що пов'язано із затемненням ВФ фразеологізму, часто спричиненим неправильним розумінням архаїзованих церковнослов'янських елементами. Затемнена ВФ уможливлює виникнення особливої групи слів і фразеологізмів - бібліїзмів-радянізмів. Продемонстровано, що наявність прозорої ВФ є причиною появи нових бібліїзмів.

У подальшому доцільно дослідити особливості вживання бібліїзмів у сучасному мовленні для з'ясування наявних семантичних девіацій й укласти словник з розробленими рекомендаціями щодо їхнього уживання. 


\section{ЛIТЕРАТУРА}

1. Багдасарян, А., \& Федуленкова, Т. (2014). Вариантность библейской фразеологии как признак системности. В Słowo. Tekst. Czas: Frazeologia w idiolekcie I systemach języków słowiańskich (W 200. rocznicę urodzin Tarasa Szewczenki). (T. 1). (c. 379-385). Szczecin - Greifswald. 2. Білодід, І. К. (Ред.) (1970-1980). Словник української мови. (Т. 1-11). Київ: Наук. думка. 3. Богачевська, І. В. (1998). Філософський аналіз мови релігії в контексті вчення О. О. Потебні. (Автореф. ... канд. філос. наук). Київ: КНУ імені Тараса Шевченка. 4. Ботвин, Т. М. (2020). Українські переклади Біблії XIX - XX століть: лінгвокультурологічний аспект. (Дис. ... канд. філол. наук). Дрогобич - Тернопіль: Терноп. нац. пед. ун-т імені Володимира Гнатюка. 5. Бугаева, И. В. (2015). Теолингвистика: теология + лингвистика. Язык и метод. Русский язык в лингвистических исследованиях ХХІ века. (Т. 2). (с 293-300). Kraków: Wydawnictwo Uniwersytetu Jagiellońskiego. 6. Буевич, А. А. (2013). К вопросу о статусе новой интегрированной дисциплины - теолингвистики. В Беларуска-руска-польскае супастаўляльнае мовазнаўства, літаратуразнаўства, культурологія (с. 132-134). Віцебск: ВДУ ім. П. М. Машэрава. 7. Єрмоленко, С. Я., Бибик, С. П., \& Тодор О. Г. (2001). Українська мова: короткий тлумачний словник лінгвістичних термінів. Київ: Либідь. 8. Зелінська, О. Ю. (2013). Украӥнська барокова проповідь: мовний світ і культурні витоки. Київ: Вид. дім Дмитра Бураго. 9. Коваль, А. П. (2012). Спочатку було Слово: крилаті вислови біблійного походження в українській мові. Київ: Либідь. 10. Коваль, А. П., \& Коптілов, В. В. (1975) Крилаті вислови в украӥнській літературній мові. Київ: Вища шк. 11. Колоїз, Ж. В., \& Бакум, З. П. (2002). Слово Благовісті: словник-довідник фразем біблійного походження. Кривий Ріг: I.B.I. 12. Лотман, Ю. М., \& Успенский, Б. А. (1973). Миф - имя - культура. Труды по знаковым системам, VI, 182-305. 13. Мокиенко, В. М. (2013). Библеизмы в европейской фразеологии и паремиологии. B Die slawische Phraseologie und die Bibel. Славянская фразеология и Библия. Slovanska frazeologia a Biblia (c. 144-153). Greifswald: Ernst-Moritz-Arndt-Universität. 14. Мокиенко, В. М. (2014). Фразеологические библеизмы: непонятное в понятном. B Słowo. Tekst. Czas: Frazeologia w idiolekcie I systemach języków słowiańskich (W 200 rocznicę urodzin Tarasa Szewczenki). (Т. 1). (с. 414-429). Szczecin - Greifswald. 15. Постовалова, В. И. (2012). Теолингвистика в современном гуманитарном познании: истоки, основные идеи и направления. Науч.-пед. журн. Восточной Сибири Magister Dixit, 4, 56-103. 16. Потебня, А. (1887). Обзоръ поэтическихъ мотивовъ колядокъ и щедровокъ. Русскій филологическій вюстникъ, 1, 30-68. 17. Потебня, А. А. (2000). Символ и миф в народной культуре. Москва: Лабиринт. 18. Потебня, А. А. (1905). Из записок по теории словесности. Харьков: Паровая Типография и Литография М. Зильберберг и С-вья. 19. Потебня, А. А. (1989). Мьсль и язык. Собр. тр. Москва: Лабиринт. 20. Потебня, А. А. (1860). О некоторьх символах в славянской народной поэзии. Харьков: В Университетской типографии. 21. Словник фразеологізмів української мови. (2008). Київ: Наук. думка. 22. Трубицына, Г. И. (2011). Перед русским народом стоит задача сохранить церковнославянский язык как язык богослужения. О Проекте документа «Церковнославянский язык в жизни Русской Православной Церкви XXI века». Узято з http://www.pravoslavie.ru/48846.html. 23. Фойту, П. (2013). Динамика библейской фразеологии как причина сходств (отличий) во фразеологии разных языков (на материале немецко-чешского словаря библейской фразеологии). Die slawische Phraseologie und die Bibel. Славянская фразеология и Библия. Slovanska frazeologia a Biblia. (c. 188194) Greifswald: Ernst-Moritz-Arndt-Universität Greifswald. 24. Chlebda, W. (2002) K описанию библеизмов в двуязычном словаре. Przegląd Rusycystyczny, 4, 86-105. 


\section{REFERENCES}

1. Bagdasaryan, A., \& Fedulenkova, T. (2014). Variantnost' biblejskoj frazeologii kak priznak sistemnosti [Variation of biblical phraseology as a feature of consistency]. In Słowo. Tekst. Czas: Frazeologia w idiolekcie I systemach języków słowiańskich (W 200. rocznicę urodzin Tarasa Szewczenki) - Word. Text. Time: Phraseology in the idiolect and systems of Slavic languages (In the 200th anniversary of Taras Shevchenko's birth). (T. 1). (pp. 379385). Szczecin - Greifswald [in Russian]. 2. Bilodid, I. K. (Ed.) (1970-1980). Slovnyk ukrainskoi movy [Dictionary of the Ukrainian language]. (T. 1-11). Kyiv: Nauk. dumka [in Ukrainian]. 3. Bohachevska, I. V. (1998). Filosofskyi analiz movy relihii v konteksti vchennia O. O. Potebni [Philosophical analysis of the language of religion in the context of the teachings of O. O. Potebnia]. Extended abstract of Doctor's thesis. Kyiv: KNU imeni Tarasa Shevchenka [in Ukrainian]. 4. Botvyn, T. M. (2020). Ukrainski pereklady Biblii XX - XXI stolit: linhvokulturolohichnyi aspect [Ukrainian translations of the Bible of the XIX - XX centuries: linguistic and cultural aspect]. Candidate's thesis. Drohobych - Ternopil: Ternop. nats. ped. un-t imeni Volodymyra Hnatiuka [in Ukrainian]. 5. Bugaeva, I. V. (2015). Teolingvistika: teologiya + lingvistika [Theolinguistics: theology + linguistics]. Yazyk i metod. Russkij yazyk v lingvisticheskikh issledovaniyakh XXI veka - Language and method. Russian language in linguistic research of the XXI century. (T. 2). (pp. 293-300). Kraków: Wydawnictwo Uniwersytetu Jagiellońskiego. [in Russian]. 6. Buevich, A. A. (2013). K voprosu o statuse novoj integrirovannoj discipliny - teolingvistiki [To the status of a new integrated discipline - theolinguistics]. In Belaruska-ruska-pol'skae supastavlyal'nae movaznavstva, litaraturaznavstva, kul'turologiya - Belarusian-Russian-Polish comparative linguistics, literary criticism, culturology (pp. 132-134). Vicebsk: VDU im. P. M. Mashehrava [in Russian]. 7. Yermolenko, S. Ya., Bybyk, S. P., \& Todor, O. H. (2001). Ukrainska mova: korotkyi tlumachnyi slovnyk linhvistychnykh terminiv [Ukrainian language: a short explanatory dictionary of linguistic terms]. Kyiv: Lybid [in Ukrainian]. 8. Zelinska, O. Yu. (2013). Ukrainska barokova propovid: movnyi svit i kulturni vytoky [Ukrainian baroque preach: language world and cultural origins]. Kyiv: Vyd. dim Dmytra Buraho [in Ukrainian]. 9. Koval, A. P. (2012). Spochatku bulo Slovo: krylati vyslovy bibliinoho pokhodzhennia v ukrainskii movi [In the beginning was the Word: winged expressions of biblical origin in the Ukrainian language]. Kyiv: Lybid [in Ukrainian]. 10. Koval, A. P., \& Koptilov, V. V. (1975) Krylati vyslovy v ukrainskii literaturnii movi [Winged expressions in the Ukrainian literary language]. Kyiv: Vyshcha shk. [in Ukrainian]. 11. Koloiz, Zh. V., \& Bakum, Z. P. (2002). Slovo Blahovisti [The Word of the Annunciation]. Kryvyi Rih: I.V.I [in Ukrainian]. 12. Lotman, Yu. M., \& Uspenskij, B. A. (1973). Mif - imya - kul'tura [Myth - name - culture]. Trudy po znakovym sistemam - Works on iconic systems, VI, 182-305 [in Russian]. 13. Mokienko, V. M. (2013). Bibleizmy v evropejskoj frazeologii i paremiologii [Biblicalisms in European phraseology and paremiology]. In Die slawische Phraseologie und die Bibel. Slavyanskaya frazeologiya i Bibliya. Slovanska frazeologia a Biblia - Slavic phraseology and the Bible (pp. 144-153). Greifswald: Ernst-Moritz-Arndt-Universität [in Russian]. 14. Mokienko, V. M. (2014). Frazeologicheskie bibleizmy: neponyatnoe v ponyatnom [Phraseological biblicalisms: incomprehensible in understandable]. In Słowo. Tekst. Czas: Frazeologia w idiolekcie I systemach języków słowiańskich (W 200 rocznicę urodzin Tarasa Szewczenki) - Word. Text. Time: Phraseology in the idiolect and systems of Slavic languages (In the 200th anniversary of Taras Shevchenko's birth). (T. 1). (pp. 414-429). Szczecin - Greifswald [in Russian]. 15. Postovalova, V. I. (2012). Teolingvistika v sovremennom gumanitarnom poznanii: istoki, osnovnye idei i napravleniya [Theolinguistics in modern humanities: origins, main ideas and directions]. Nauch.-ped. zhurn. Vostochnoj Sibiri Magister Dixit - Scientific and pedagogical 
journal of Eastern Siberia Magister Dixit, 4, 56-103 [in Russian]. 16. Potebnya, A. (1887). Obzor poe'ticheskix motivov kolyadok i shhedrovok [Review of poetic motives of Christmas carols]. Russkij filologicheskij vnostnik - Russian philological journal, 1, 30-68 [in Russian]. 17. Potebnya, A. A. (2000). Simvol i mif v narodnoj kul'ture [Symbol and myth in folk culture]. Moskva: Labirint [in Russian]. 18. Potebnya, A. A. (1905). Iz zapisok po teorii slovesnosti [From notes on the theory of literature]. Khar'kov: Parovaya Tipografiya i Litografiya M. Zil'berberg i S-v'ya [in Russian]. 19. Potebnya, A. A. (1989). Mysl' i yazyk [Thought and language]. Moskva: Labirint [in Russian]. 20. Potebnya, A. A. (1860). O nekotoryx simvolax $v$ slavyanskoj narodnoj poe'zii [Some symbols in Slavic folk poetry]. Khar'kov: V Universitetskoj tipografii [in Russian]. 21. Slovnyk frazeolohizmiv ukrainskoi movy [Dictionary of phraseology of the Ukrainian language]. (2008). Kyiv: Nauk. dumka [in Ukrainian]. 22. Trubicyna, G. I. (2011). Pered russkim narodom stoit zadacha sokhranit' cerkovnoslavyanskij yazyk kak yazyk bogosluzheniya. O Proekte dokumenta «Cerkovnoslavyanskij yazyk v zhizni Russkoj Pravoslavnoj Cerkvi XXI veka» [The Russian people are faced with the task of preserving the Church Slavonic language as the language of worship. On the Draft Document «Church Slavonic Language in the Life of the Russian Orthodox Church of the XXI Century»]. Retrieved from http://www.pravoslavie.ru/48846.html [in Russian]. 23. Fojtu, P. (2013). Dinamika biblejskoj frazeologii kak prichina skhodstv (otlichij) vo frazeologii raznykh yazykov (na materiale nemecko-cheshskogo slovarya biblejskoj frazeologii) [The dynamics of biblical phraseology as the cause of similarities (differences) in the phraseology of different languages (based on the material of the German-Czech dictionary of biblical phraseology)]. Die slawische Phraseologie und die Bibel. Славянская фразеология и Библия. Slovanska frazeologia a Biblia - Slavic phraseology and the Bible (pp. 188-194). Greifswald: Ernst-Moritz-Arndt-Universität Greifswald [in Russian]. 24. Chlebda, W. (2002) K opisaniyu bibleizmov v dvuyazychnom slovare [To a description of biblicalisms in a bilingual dictionary]. Przegląd Rusycystyczny - Russian Review, 4, 86-105 [in Russian].

Піддубна Наталія Віталіївна - кандидат філологічних наук, доцент, доцент кафедри української мови, Харківський національний педагогічний університет імені Г. С. Сковороди; вул. Валентинівська, 2, Харків, 61168, Україна.

Tel.: +38 0974396510

E-mail : piddubnan71@gmail.com

http://orcid.org/0000-0003-0331-0496

Piddubna Nataliia Vitaliivna - Ph.D. in Philology, Docent, Associate Professor at the Department of Ukrainian Language, H. S. Skovoroda Kharkiv National Pedagogical University; Valentynivska Str., 2, Kharkiv, 61168, Ukraine.

Надійшла до редакції 08 вересня 2020 року

\section{CITATION}

ДСТУ 8302:2015: Піддубна Н. В. Інтерпретація внутрішньої форми біблійних фразеологізмів - актуальна проблема теолінгвістики. Лінгвістичні дослідження: зб. наук. пр. Харк. нац. пед. ун-ту імені Г. С. Сковороди. Харків, 2020. Вип. 53. С. 28-40. DOI: https://doi.org/10.34142/23127546.2020.53.03

AРА: Піддубна, Н. В. (2020). Інтерпретація внутрішньої форми біблійних фразеологізмів - актуальна проблема теолінгвістики. Лінгвістичні дослідження, 53, 28-40. DOI: https://doi.org/10.34142/23127546.2020.53.03 